\title{
Penetrating eye injury by dart
}

\author{
Tanja Germerott $^{1}$ (D) $\cdot$ N. Mann ${ }^{1} \cdot$ S. Axmann ${ }^{1}$
}

Received: 10 March 2020 / Accepted: 9 December 2020 / Published online: 17 December 2020

(C) The Author(s) 2020

\begin{abstract}
Darts are constantly gaining in popularity. However, their risk of injury is often underestimated. This report is about a juvenile who suffered from a severe eye injury including the opening of the eye bulb. The attending ophthalmologists ruled out the possibility that this kind of injury could be caused by a dart with a plastic point. However, by reconstructing the course of action and throwing darts at porcine eyes, the forensic medical advisory opinion was able to state that darts with damaged plastic points may cause the exact same form of injury. This casuistic illustrates the essential significance of forensic-traumatological knowledge and, especially in the case of rare injury patterns, case-related practical experiments.
\end{abstract}

Keywords Dart $\cdot$ Eye injury $\cdot$ Eye bulb injury $\cdot$ Penetrating eye injury $\cdot$ Foreign body

\section{Introduction}

The game of darts originated in the early 20th century. It is constantly increasing in popularity not only for leisure activities but also for highly endowed competitive sports [1]. Every dart has four parts: the point (or tip), barrel, shaft, and flight [2]. In medical literature, there are only few casuistic reports or case series of eye injuries caused by darts. In the majority of these cases the injuries were caused by the points, which come in plastic or steel versions, or the flights [3-5]. In general, darts bear a relevant risk of injury if used carelessly or improperly.

Children and juveniles are the most highly endangered age groups for suffering an eye injury. About $25 \%$ of all penetrating eye injuries can be found in these age groups, males predominating over females [3, 6-8].

The report below presents a rare case of a perforating eye injury caused by the plastic point of a dart.

\section{Casuistic}

A 16-year-old female juvenile underwent eye surgery after having suffered a perforating scleral bulb injury along the limb

Tanja Germerott

germerott@uni-mainz.de

1 Institute of Legal Medicine, University Medical Center of the Johannes Gutenberg University Mainz, Am Pulverturm 3, 55131 Mainz, Germany with a prolapse of iris tissue, ranging between 12 and 4 o'clock according to the clinical reports. There were no further injuries, especially facial or around the eyes, documented in the medical records. Prior to surgical treatment, no photography was taken. After the juvenile's discharge from hospital, her visual acuity constituted $1 \%$.

According to police inquiry, the injured person had visited a Christmas market and sat on a metal fence. Nearby, three juveniles had fooled around with a plastic-tipped dart, which they had stolen from a bar. Supposedly the dart had been purposefully thrown to the ground to make it stick in the soil. Finally, one of the juveniles had thrown the dart nondirectional to the side in order to prevent harm. From the corner of her eye, the injured person had seen something flying towards her, followed by a sudden pain in the eye. Afterwards, the dart had fallen to the ground. When interrogated, she negated having tumbled. The dart had been unable to seize.

During the following trial, two ophthalmologists from the treating hospital testified that the pattern of injury described above could not be induced by a dart's point, stating that in this case the injury would have to be punctual. Furthermore, they testified that in this particular case something would have to hit the eye with $100 \mathrm{~km} / \mathrm{h}$ and that the injury in question seemed to have been caused by falling on the edge of a table, regardless of the juvenile's statement that she had not tumbled.

Eventually, a forensic medicine's advisory opinion was obtained. Darts were first dropped on the eyes from a height 
Table 1 List of test results with hand-thrown darts at a distance of $2 \mathrm{~m}$

\begin{tabular}{llll}
\hline Throw no. & Throw distance $d(\mathrm{~m})$ & Travel time $t(\mathrm{~s})$ & Average speed $(\mathrm{m} / \mathrm{s})$ \\
\hline 1 & 2 & 0.19 & 10.53 \\
2 & 2 & 0.20 & 10.00 \\
3 & 2 & 0.19 & 10.53 \\
4 & 2 & 0.19 & 10.53 \\
5 & 2 & 0.21 & 9.52 \\
6 & 2 & 0.20 & 10.00 \\
7 & 2 & 0.19 & 10.53 \\
8 & 2 & 0.21 & 9.52 \\
9 & 2 & 0.19 & 10.53 \\
10 & 2 & 0.20 & 10.00 \\
\hline
\end{tabular}

* Average speed rounded two decimal places of $10 \mathrm{~m}$ using a drop tube. The average speed of the darts was determined by means of time measurements (Table 1). The series of tests have shown that darts with metal tips can result in serious injuries and perforations of the eyeball. Darts with undamaged plastic tips caused only slight visible, isolated injuries to the cornea. Darts with three kinds of points were then thrown at porcine eyes for information assessment: steel points, plastic points, and modified plastic points, simulating the damage of the dart point described above by pinching it off (Fig. 1). The darts were thrown by hand at the porcine eyes, which were embedded in styrofoam for fixation. Darts were thrown by hand over 50 times, but only few darts hit the porcine eye (no experience in darts was present). But finally after one throw, injury very similar to the juvenile's was induced by a dart with a pinched-off point (Fig. 2).
The kinetic energy of the points added up to $0.84 \mathrm{~J}$ in throws from a 5-m distance. The flight of the dart did not result in an opening of the bulb, neither by throwing it nor by cutting the porcine eye with it. There were only superficial corneal lesions definable.

In the end, the charge was dismissed due to diverging testimony and the missing evidence weapon.

\section{Discussion}

The incidence of treatment-demanding eye injuries amounts to $810 / 100,000$ inhabitants [9]. The high number of eye injuries is not just a socio-economic issue but also one of the main causes of amaurosis [10-12]. By introducing a mandatory seatbelt in
Fig. 1 a Dart and plastic points. The upper one unscathed the one down below with a modified plastic point. b Injury to the pig's eye (red arrow)

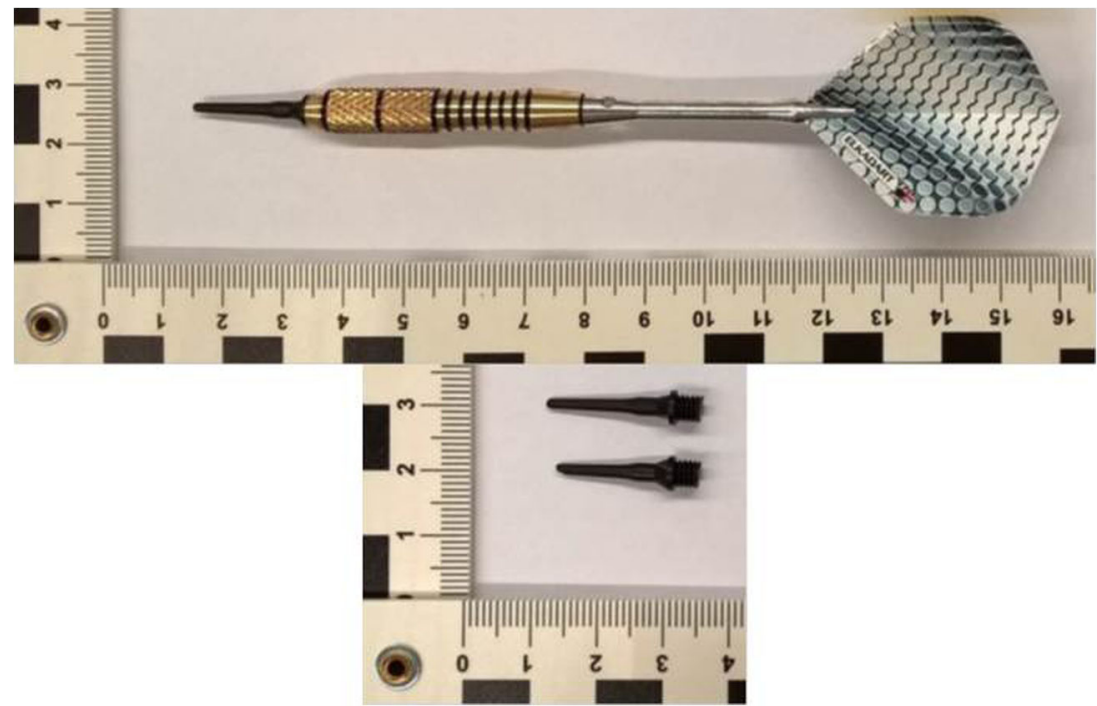




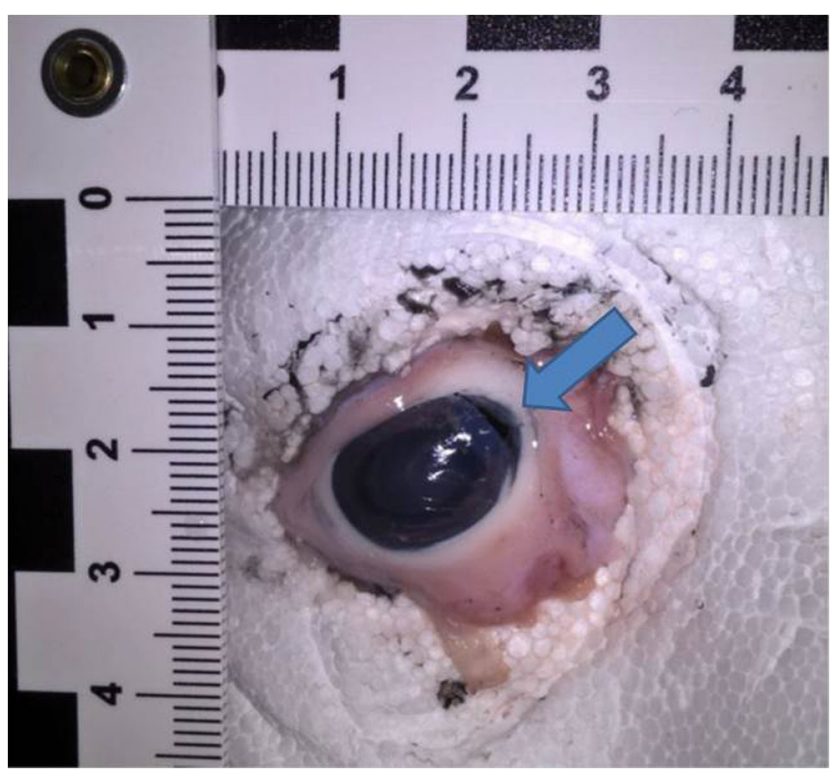

Fig. 2 An injury very similar to the juvenile's, induced by a dart with a pinched-off point

England in 1983, perforating eye injuries were lowered by $11.1 \%$. This underlines the impact of simple primary preventional actions on the incidence of eye injuries [6]. In literature, there are various cases of partly perforating eye injuries caused by diverse objects such as durian fruit, fishing gear, or darts $[3,4,13,14]$. The rather rare eye injuries caused by darts mostly lead to a fulminant reduction of visual acuity and lots of after treatment due to persistent vitreous body bleedings [3, 4]. These dramatic etiopathologies and the high potential of injury should be kept in mind when handling darts. There are over-thecounter soft-air guns whose projectiles generate a kinetic energy from $0.5 \mathrm{~J}$ up to $7.5 \mathrm{~J}[15,16]$. These "toy" guns carry an immense risk of injury, considering that corneal lesions occur at $0.184 \mathrm{~J}$ already [17]. Soft air guns subject to weapons law when generating a kinetic energy of $\geq 0.5 \mathrm{~J}$, resulting in strict terms of carrying and using them [16]. In the present case, the kinetic energy of a thrown dart added up to $0.84 \mathrm{~J}$, which is comparable to the lower kinetic energy of soft air guns.

In this particular case, a forensic medicine's opinion was obtained only due to the conflicting testimony of the ophthalmologists and the injured person. Especially in scarce patterns of injury, a forensic-traumatologic expertise is mandatory for information evaluation and reconstruction, which in this case proved that falling on a table's edge when there were no other injuries on exposed body parts cannot have been causal for the described eye injury.

Since dart-related injuries are rare, the present case illustrates the essential significance of case-related practical experiments as an essential element of forensic medicine. Against the ophthalmologists' statement, they were able to prove that a pinched-off darts point may very well cause a bulb injury comparable to the one described.

Acknowledgements Open Access funding enabled and organized by Projekt DEAL.

Authors' contribution All authors contributed to the case report. Material preparation, data collection, and analysis were performed by Tanja Germerott und Stefan Axmann. The first draft of the manuscript was written by Nikolas Mann, and all authors commented on previous versions of the manuscript. All authors read and approved the final manuscript.

\section{Compliance with ethical standards}

This research did not involve human participants or animals. The porcine eyes were slaughterhouse waste.

Conflict of interest The authors declare that they have no conflict of interest.

Open Access This article is licensed under a Creative Commons Attribution 4.0 International License, which permits use, sharing, adaptation, distribution and reproduction in any medium or format, as long as you give appropriate credit to the original author(s) and the source, provide a link to the Creative Commons licence, and indicate if changes were made. The images or other third party material in this article are included in the article's Creative Commons licence, unless indicated otherwise in a credit line to the material. If material is not included in the article's Creative Commons licence and your intended use is not permitted by statutory regulation or exceeds the permitted use, you will need to obtain permission directly from the copyright holder. To view a copy of this licence, visit http://creativecommons.org/licenses/by/4.0/.

\section{References}

1. Exner P de d (2020) Impressum. https://www.dartn.de/imprint/. Accessed 16 Jan 2020

2. Der Dart - Dartpfeil. https://alles-dart.de/dartpfeil.php. Accessed 16 Jan 2020

3. Cole MD, Smerdon D (1988) Perforating eye injuries caused by darts. Br J Ophthalmol 72:511-514. https://doi.org/10.1136/bjo.72.7.511

4. Thill-Schwaninger M, Marquardt R (1988) Perforating eye injuries caused by darts. Klin Monatsbl Augenheilkd 192:699-702. https:// doi.org/10.1055/s-2008-1050207

5. Patel BC (1989) Penetrating eye injuries. Arch Dis Child 64:317320. https://doi.org/10.1136/adc.64.3.317

6. Cole MD, Clearkin L, Dabbs T, Smerdon D (1987) The seat belt law and after. Br J Ophthalmol 71:436-440. https://doi.org/10. 1136/bjo.71.6.436

7. Adhikary HP, Taylor P, Fitzmaurice DJ (1976) Prognosis of perforating eye injury. Br J Ophthalmol 60:737-739. https://doi.org/10. 1136/bjo.60.11.737 
8. Canavan YM, O'Flaherty MJ, Archer DB, Elwood JH (1980) A 10year survey of eye injuries in Northern Ireland, 1967-76. Br J Ophthalmol 64:618-625. https://doi.org/10.1136/bjo.64.8.618

9. Mönestam E, Björnstig U (1991) Eye injuries in northern Sweden. Acta Ophthalmol 69:1-5. https://doi.org/10.1111/j.1755-3768.1991. tb01982.x

10. Fong LP (1995) Eye injuries in Victoria, Australia. Med J Aust 162:64-68

11. Négrel AD, Thylefors B (1998) The global impact of eye injuries. Ophthalmic Epidemiol 5:143-169. https://doi.org/10.1076/opep.5. 3.143.8364

12. Thylefors B (1992) Epidemiological patterns of ocular trauma. Aust N Z J Ophthalmol 20:95-98. https://doi.org/10.1111/j.1442-9071. 1992.tb00718.x

13. Reddy SC (2012) Ocular injuries by durian fruit. Int J Ophthalmol 5:530-534. https://doi.org/10.3980/j.issn.2222-3959.2012.04.25

14. Viestenz A, Küchle M (2001) Retrospective analysis of 417 cases of contusion and rupture of the globe with frequent avoidable causes of trauma: the Erlangen Ocular Contusion-Registry (EOCR) 1985 - 1995. Klin Monatsbl Augenheilkd 218:662-669. https://doi.org/10.1055/s-2001-18388

15. Rechtslupe (2019) Waffenrecht-Ratgeber - diese Regelungen gelten für Airsoftwaffen | Waffenrechtslupe. https://www. waffenrechtslupe.de/waffenrecht-ratgeber-diese-regelungengelten-fuer-airsoftwaffen-76130. Accessed 16 Jan 2020

16. WaffG - Waffengesetz. https://www.gesetze-im-internet.de/waffg 2002/BJNR397010002.html. Accessed 16 Jan 2020

17. Duma SM, Ng TP, Kennedy EA, Stitzel JD, Herring IP, Kuhn F (2005) Determination of significant parameters for eye injury risk from projectiles. J Trauma 59:960-964. https://doi.org/10.1097/01. ta.0000174830.55282.32

Publisher's note Springer Nature remains neutral with regard to jurisdictional claims in published maps and institutional affiliations. 